\title{
THE THIRD SPACE AND THE ROLE OF BUNDO KANDUANG IN RUMAH GADANG
}

\author{
Rosalinda Wiemar1*, Yasraf Amir Piliang ${ }^{2}$,Deddy Wahjudi³, Ruly Darmawan ${ }^{4}$ \\ 1,23,4 Faculty of Art and Design, Bandung Institute of Technology, Jl. Ganesha No.10. Bandung 40132, INDONESIA \\ *Corresponding author, Email: rosalindaw@student.itb.ac.id
}

\begin{abstract}
Minangkabau is a tribe in West Sumatra with a matrilineal kinship system, which draws lineage based on the mother's ethnicity. Therefore, women are the main characters in the tribe. Minangkabau women who are married, wise, and elder are called Bundo Kanduang, who have duties and obligations to carry out. Given the importance of the role of Bundo Kanduang, it is necessary to know how the role of Bundo Kanduang can be carried out in the Rumah Gadang, both physically/real and non-physical/imaginary. The research method used is an ethnographic method with a qualitative analysis approach using the theory of the third space from Edward Soja. Based on the analysis, it was found that the activities of Bundo Kanduang in carrying out its role have been facilitated in the Rumah Gadang, both physically and non-physically, even beyond what is known as third space.
\end{abstract}

Keywords: Bundo Kanduang; Minangkabau; matrilineal; rumah gadang; the third space.

\section{INTRODUCTION}

Minangkabau is a tribe in West Sumatra, which has a culture in the form of values, norms, rules that govern the social system of its people. The social system for the categories of men and women in Minangkabau ethnic culture has a certain position and role. Women in customary rules have a role in determining lineage and inheritance through the mother's line (matrilineal understanding). The position and role of Minangkabau women have been regulated and regulated by custom. Customs regulate women's behavior in social systems, kinship systems, lineage, boundaries of the social environment between relatives, principles of heredity, the position of inheritance and inheritance. Women are very important in adat, meaning that the position of women is the foundation of the hope of their generation. For married women, having a wise and elder attitude is called Bundo Kanduang. He was not appointed, elected, or claimed to be Bundo Kanduang, but his dignity rose naturally. The name Bundo Kanduang means that, in addition to the virtues given, Bundo Kanduang also has duties and obligations that must be carried out as a foothold when carrying out activities. Bundo Kanduang's activities in the Rumah gadang are a form of his role in adat, both real and unreal. Its role can still be felt and meaningful even though it is not tangible.

Rumah gadang, as a traditional house owned by the tribe, is the main facility for daily activities and traditional ceremonies. Rumah gadang is a shared living house, in which there live several sajurai families, namely descendants of one grandmother.
Rumah gadang tribe is a symbol that contains the meaning of Minangkabau traditional philosophical values that must be practiced in everyday life. For the Minangkabau people, the Rumah gadang is not merely a place to live, but the Rumah gadang is a symbol of the existence of a people under a traditional umbrella led by a penghulu who gets the title Datuk. This provision is the background to the question that often arises, namely why women are the main figures in the tribe, but tribal leaders are men. Bundo Kanduang as a representative of women should have a special 'place' in the Rumah gadang, especially in the interior of the house as the main facility for daily activities and traditional ceremonies. Furthermore, Bundo Kanduang, as the main figure in the tribe, is always involved in activities in the Rumah gadang.

The distinctive shape of the building, the unique layout, and division of space in the Rumah gadang are sources of information that need to be explored in the form of research because not all of Bundo Kanduang's facilities can be seen in real terms, so it seems as if Bundo Kanduang has no special 'place' in the Gadang house. In fact, the previous traditional leaders have formulated it in custom and made it in such a way that Bundo Kanduang gets facilities in order to be able to carry out his role properly, in accordance with the tasks and obligations given.

Edward Soja's thought in the form of the third space concept above is also a sharpening of the heterotopia concept of space from Michael Foucault. The third space of Soja is a space that moves between real space, which has a physical dimension, and an unreal space, namely the space in ideas, thoughts that 
have abstract dimensions. The character of this space is real, and its existence can be felt, but in other circumstances or situations, it can have an unreal, virtual character or disappear from view. According to Soja, it is real and imagined, namely as a continuum that can produce unlimited possibilities of space and the notion of space as a social construction (Soja, 1996).

Michael Foucault states that heterotopia is a concept of relative space, and in extreme conditions, a real space can shift into an unreal space or from a profane character to a sacred character or vice versa. Contrary to the understanding of utopian space, which is an ideal space that is never real, Foucault's heterotopic space is a real space with a relative unreal dimension and has the potential to shift over time and different activities (Foucault, 1998).

Because not all the facilities of the Bundo Kandung space can be seen as real, this research will use space theory that considers Edward Soja's imagination/unreal space, namely The Third Space, to analyze the spatial facilities in the role of Bundo Kanduang, especially in the interior of the Rumah gadang. The concept of third space is focused on its use in revealing the meaning of space, especially those that are not really related to the role of Bundo Kanduang in carrying out the duties and obligations and the facilities available at the Rumah gadang.

Given the importance of the role of Bundo Kanduang for the progress of the Minangkabau community, this research was conducted in order to find out what the facilities for Bundo Kanduang's activities are like in the building of the Rumah gadang while carrying out their duties and obligations. The results obtained are expected to be a guide for the building and interior of the Rumah gadang and documented so that it is sustainable so that it can be passed on to future generations.

\section{METHODOLOGY}

The method used is the ethnographic method. The use of the method is focused on recording the activities of residents in the Rumah gadang. In particular, it is related to the role of Bundo Kanduang, who has duties and obligations in carrying out his role in the Rumah gadang. Based on Creswell, 2007, research procedures with ethnographic methods were carried out as follows: a. Identify the object of research, namely Rumah gadang, located in the Sungai Puar area, and share its culture for study. Choosing a Gadang house, with a house in good condition, is still used as a place to live, and Bundo Kanduang's role is still actively carried out. b. Describing how the com- munity is active and represents Minangkabau customs in the interior of the Rumah gadang is associated with the role of Bundo Kanduang, based on the theoretical framework of the literature data. c. Collecting information from the field (fieldwork), in-depth interviews so as to obtain sharp answers, and visual mapping. $d$. Conduct in-depth analysis and interpretation of the sources gathered. e. Compile detailed descriptions, which contain the views of participants (emic), namely traditional stakeholders, community leaders, residents of traditional houses, and the figure of Bundo Kanduang and researchers (etic).

Data collection methods include two sources of data, namely: literature data and field data. Literature data found that is associated with topics and grouped based on scientific fields, namely: Space, Minangkabau customs, with sub-discussions regarding the duties and obligations of Bundo Kanduang, as well as activities and facilities in the Rumah gadang. Field data was obtained through participant observation, interviews with informants who were chosen intentionally according to their needs, and the collection of artifacts. Observations were made in the Rumah gadang, especially when Bundo Kanduang played a role in activities during preparation, implementation, and post-implementation.

Direct mapping is carried out during observations or carried out later based on records. The mapping procedure consists of five basic elements, namely: (a) A rough sketch of the area or setting that will be observed in the Rumah gadang; (b) A clear definition of the form of behavior that will be observed when activities are carried out at the Rumah gadang; (c) Making plans for observation time, to obtain data on the role of Bundo Kanduang as needed through informants and resource persons through the interview method; (d) Following a systematic procedure during observation.

The data collected consists of two kinds: (a) Primary data is data obtained directly from the source, namely regarding Minangkabau customs in general and specifically related to the Rumah gadang and Bundo Kanduang; (b) Secondary data is data that the researcher does not attempt to collect himself but is supportive and completes the primary data.

Data triangulation is carried out to better understand complex problems, difficult to decide so that they can be viewed from various perspectives. Triangulation of field data was carried out through indepth interviews with several informants so that valid data was obtained.

The data analysis method uses a qualitative research approach with descriptive analysis. More analysis describes the facts as they are. During the analysis 
process, compare, and contrast techniques are used to identify similarities and differences between categories to find patterns (Leedy, 1997). Conclusions are made as part of the overall research. Conclusions are verified during the activity.

\section{SPACE AT RUMAH GADANG}

It is known that there is a very close relationship between space and activity, in this case, related to the human culture of its inhabitants, that space that has become a place such as a house, village, and its environment is a facility/container for individual activities and social behavior shown, and lasts all the time. Thus, the artificial environment is a product that is built from the reciprocal relationship between the user and their living space. Discussing the relationship between the space and the role of Bundo Kanduang in the Rumah gadang, it is necessary to know the activities carried out and the facilities, especially in the interior of the Rumah gadang.

Amos Rapoport said that, basically, there is a relationship or reciprocal relationship between space and humans and the people who use or inhabit space (Rapoport, 1974). In this view, there are differences in human behavior or society in utilizing space. As there are specific differences in each region, so there is the cultural diversity that is human in nature. Therefore, the space created has a plural and different meaning and value, depending on the behavior and lifestyle of the individual or community group that uses the space. In other words, aspects of norms, views of life, or different cultures of society will produce different conceptions and forms of space (Rapoport, 1974), as shown in Figure 1. In this context, space in Rapoport's work is more often referred to as a setting, which shows the interaction between humans and space.

Based on the provisions of Minangkabau customs, it is implied that Bundo Kanduang has very important duties and obligations in order to advance his people. The important and heavy role that Bundo Kanduang carries is balanced with supporting facilities in the form of space facilities for Bundo Kanduang's activities. Spatial facilities to support Bundo Kanduang's activities have been conceptualized by traditional stakeholders since ancient times, implied in traditional proverbs which have very deep meanings. In order for Bundo Kanduang's role to be carried out properly, the predecessors had imagined what facilities would be needed so as to provide progress for the community within their clan. One of them is a Gadang house with the shape it looks like today. The conceptualized facilities do not always look real, but their meaning and function can still be fully felt by the residents of the Rumah gadang.

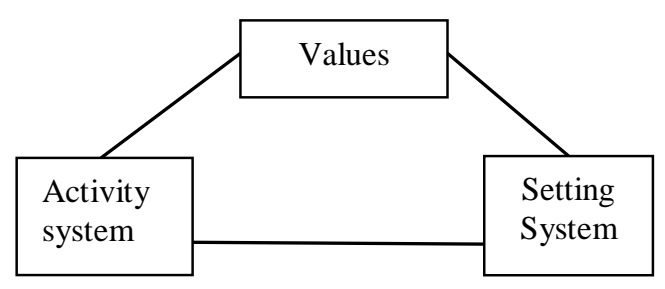

Fig. 1. The triangular relationship between values- activity system - setting system (Source: Sudaryono in Triatmodjo, 2010).

An understanding of real and unreal spaces can be linked to the concept of The Third space from Edward Soja, 1996: which originated from Soja's thought that there are other spaces besides real and unreal spaces. In the past, space was interpreted in relation to time/history. All events were related to the time of the incident. For geographers, it has not focused attention on society. Meanwhile, according to Soja, the three things were inseparable. Community activity will produce space, and space will produce society within a certain period of time. This connection is known as the socio-spatial dialectic. According to Soja, the concept of the third space is the development of the first space and the second space. It was explained that the first space is a physical, real space, a place, and a facility for human activities to take place. The second space is a space of imagination, about how meaningful space should be in the form of ideas, thoughts, or concepts. The second space is an unreal space or space for the imagination. In this space, the concept of space from architects, government, or traditional figures conceptualizes the ideal space for their people to be realized. Meanwhile, the third space is a combination of first space and second space, which is the combination of real space and imagination, which is inseparable. The third space is a state when a person can feel his or her presence while carrying out activities so that they can analyze and reflect through the events that occur to them. Soja also stated that the third space is a moving space that is between the real space with the physical dimension and the unreal space, namely the space that comes from ideas, concepts, thoughts that exist in the imagination and have an abstract dimension. Socialization will give meaning to space, and everyone can feel things that are not the same.

The role of Bundo Kanduang has been arranged in the form of duties and obligations, which are very meaningful, facilitated in the Rumah gadang physically and non-physically/imaginary. Therefore, Soja's theory in the form of the first place, second-place, and third-place concepts will be used as a basis for analyzing the space available as a Bundo Kanduang facility in the Rumah gadang. 


\section{DUTIES AND OBLIGATIONS OF BUNDO KANDUANG}

In Minangkabau custom, it is taught to instill respect and honor women as greatness in the life of a tribe and family, which makes it a symbol of descent in Minangkabau matrilineal understanding. An adult woman who is married, authoritative, has wisdom, understands Minangkabau customs, and can maintain balance in her extended family is called Bundo Kanduang by the Minangkabau people. Bundo Kanduang was given a number of exceptions and privileges in the life of the people when compared to men, with the aim of being protected from all forms and actions that would bring down the very noble dignity of women. In accordance with its important role as a woman in society, Bundo Kanduang also has a very important role besides men who are leaders in the tribe, both in daily activities and in traditional events. Broadly speaking, the role of Bundo Kanduang in customs in the form of duties and obligations consists of four kinds, as stated in the Minangkabau traditional proverb, which is the basis for carrying out the role as a woman (Ernatip, 2014), namely:

1. Manuruik alua nan luruih (following a straight path)

The meaning of alua is that every provision in Minangkabau custom is based on the provisions and propriety

2. Manampuah jalan nan pasa (taking the usual path).

According to custom, it has a figurative meaning, that every path taken is a way to get to the goal, both in this world and in the hereafter.

3. Mamaliharo harato pusako (maintaining heirlooms).

According to Minangkabau custom, harato pusako is an inheritance that has been determined by custom. This property must be maintained so that it does not run out or move to another country, unless it is used for the public interest through an agreement in deliberation.

4. Mamaliharo anak dan kemenakan (care for nephews).

In a broad sense, it is the main obligation and task in the life of Bundo Kanduang in Minangkabau, which in its implementation is to command good deeds and prohibit evil/bad deeds.

Through the duties and obligations of Bundo Kanduang, the room facilities in the rumah gadang will be studied which support the role of Bundo Kanduang when carrying out activities in the rumah gadang based on the spatial theory of Edward Soja.

\section{DISCUSSION AND RESULTS}

The role is a set of behavior that is expected to be possessed in society, as well as the role of Bundo Kandung in the Minangkabau tribes. The role as a practice of the duties and obligations of Bundo Kanduang is contained in the activities carried out in the rumah gadang building. Thus, there is a reciprocal relationship or relationship between the facilities in the rumah gadang building and the people who use or inhabit the space.

Aspects of norms, views of life or culture of the typical Minangkabau society produce the conception and form of space that shows the interaction between humans and space in the form of setting. Furthermore, in the activities of the community, users and residents of the gadang house will produce space and space will produce society within a certain period of time (sociospatial dialectic). According to Soja, the concept of the third space is the development of the first space and the second space.

First space is a physical space, real, a place and a facility for ongoing activities such as the activities of residents in a gadang house. Second space is an unreal space or an imaginary space. In this space, the concept of space for the traditional predecessors conceptualized the ideal space for their people to be realized. Especially for Bundo Kandung, traditional leaders have long created ideal concepts in the form of tasks and obligations that are related to facilities, especially the space found in the rumah gadang. The real and unreal spaces found in the rumah gadang are activity facilities, so that Bundo Kandung can carry out their roles well.

This research focuses on the activities of Bundo Kanduang as the central figure in the matrilineal understanding adopted by the Minangkabau community associated with the concept of space that has been made by traditional leaders in the rumah gadang. The facilities for the activities of Bundo Kanduang will be discussed according to the duties and obligations of Bundo Kanduang and analyzed based on the space theory of Edward Soja as follows.

\section{Manuruik alua nan luruih (following a straight path).}

Alua (groove) means that the provisions in Minangkabau customs are based on provisions and propriety,

Provisions and propriety in the life of the Minangkabau people have been regulated according to the customs and teachings of Islam. One of them is alua pusako, namely customary provisions that have 
been outlined by traditional stakeholders as leaders from a long time ago, associated with inheritance for women, such as houses, rice fields, and fields that can be used for the common interest of one or more people. Rumah gadang is a traditional building that is shared in one tribe, inhabited by several families who are saparuik (originating from one grandmother's stomach) (Figure 2).

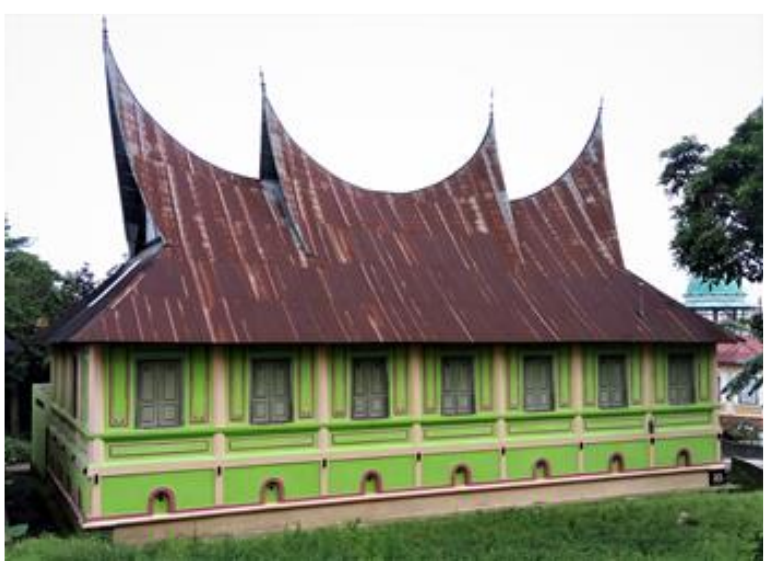

Fig. 2. Rumah gadang which belongs to the custom is used for the common interest of one tribe

Physically, the rumah gadang belongs to one clan, which functions as a residence and a symbol of the existence of a tribe. Rumah gadang is one of the harato pusako (heirloom treasures) which are inherited by women from one grandmother which cannot be traded except in an emergency and has been agreed upon in community meetings. The combination of the real space in the form of the rumah gadang building and customary provisions that give priority to living for women and children as well as the ownership of the rumah gadang for generations on behalf of the descendants of one grandmother (saparuik), provides a sense of security and protection for the occupants of the rumah gadang and Bundo Kanduang in carrying out his role.

\section{Manampuah jalan nan pasa (taking the usual path).}

According to the custom, this proverb has a figurative meaning, namely that every path taken is a way to get to the goal, both in this world and in the hereafter.

The physical space in the rumah gadang is divided into several spaces, namely: the living room and bilik (bedroom/KT). The living room (Figure 3) functions as a center for the activities of the rumah gadang, both for daily activities such as holding tribal deliberations, conducting various ceremonies, holding banquets, and releasing men who are married (after leaving the houses of their wives and children) for the funeral when they die. Every activity carried out in the rumah gadang, especially in traditional activities, is separated between men and women. Physically, there are no boundaries in this space, but the open and wide form of space, when needed, can be used as an imaginary space that divides groups of men and women. At the time of deliberation, family meetings, banquets, the task of providing the needs of each activity will be adjusted according to the group. Male guests are served by men and female guests are served by women. This provision follows the teachings of the Islamic religion which separate the activities of men and women who are not their muhrim (Figures 3 and 4).

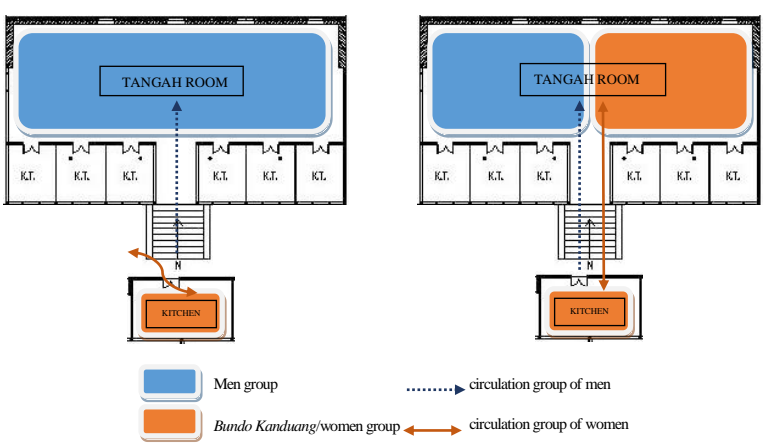

Fig. 3. The division of space for men and Bundo Kanduang in the living room

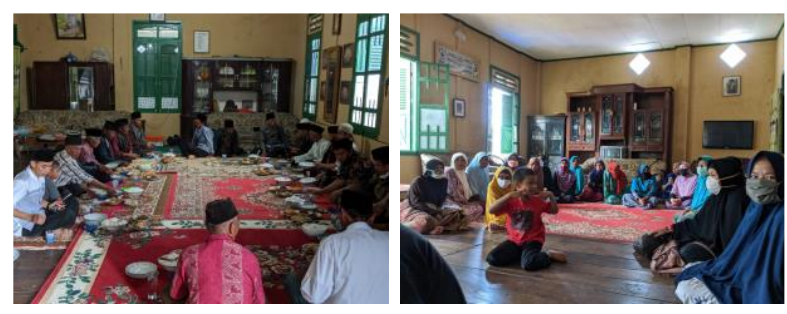

Fig. 4. Men (left image) and Bundo Kanduang (right image) sit separately in traditional events

Customs in Minangkabau are always based on the teachings of Islam, contained in the customary proverb: Adat basandi syarak, syarak basandi Kitabullah, which means: customs carried out by the Minangkabau community must be based on Islamic law, and Islamic law is in the Koran.

In daily activities, the living room is a means of residents' activities such as: eating, receiving guests, family events, and others. The division of the living room is based on the boundaries of each room (Figure 5). Physically, there are no boundaries between one bilik and another, but there is a limiting imagination space according to the traditional concept so that each occupant uses his/her territory according to the position of their respective bilik. 


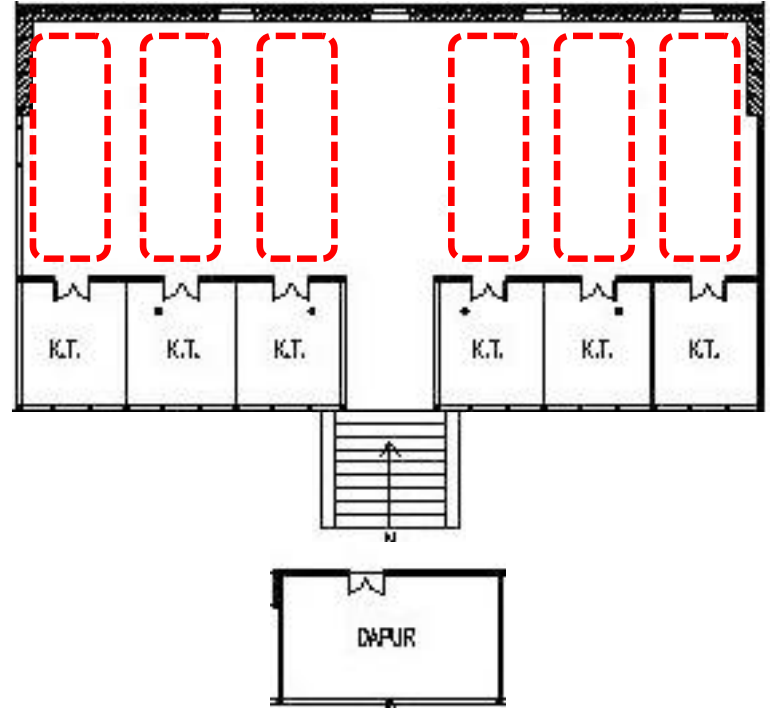

Fig. 5. The distribution of the use of the living room zone for the occupants of the rumah gadang based on the position of the cubicle

The division of the use of the living room zone is based on the position of the bilik, in accordance with customs that refer to the teachings of Islam to the residents of the rumah gadang to always use the zone according to their rights and not to take the zone of fellow residents of the rumah gadang. For Bundo Kanduang, the division of the imagination zone is a reminder to always be fair and not discriminate in carrying out his role.

Minangkabau custom separates the activities of women and men, especially in the living room and the division of the living room zone based on the bilik is a space facility given to Bundo Kanduang so that he can carry out his role properly in accordance with Islamic teachings so that he can bring his people to a good goal in the community, world and in the hereafter.

\section{Mamaliharo harato pusako (maintain the inheri- tance).}

According to Minangkabau custom, harato pusako is an inheritance that has been determined by custom. This property must be maintained so that it does not run out or move to another country, unless it is used for the public interest through an agreement in deliberation.

The main source of income for the residents of the rumah gadang who come from harato pusako is from the fields. Generally used as a place to grow crops, the results of which can be used alone or sold to get money to buy other necessities. The kitchen area in the rumah gadang is a very important part of the house. The welfare of the residents can be seen from the activities in the kitchen, which serve as a means of processing food ingredients for the lives of the residents of the gadang house. The kitchen as a physical space is the main area in Bundo Kanduang's task, especially in processing the sources of life for the residents of the house that are sourced from the heirlooms of their people, such as cooking food ingredients that come from the tribal fields. The location of the kitchen and the entrance are opposite each other. The entrance to the rumah gadang is a means for the main activities of the residents and guests of the gadang house to enter and exit the gadang house, both for men and women. On the facade of the building, there are several types of door locations, namely on the front, side and back of the house. In this study, it is focused on the door of the rumah gadang, which is located at the back.

The location of the kitchen is in front of the entrance to the gadang house, so every time you enter the house, you have to pass through the kitchen. Imaginably, this location facilitates and facilitates the task of Bundo Kanduang in terms of maintaining heirlooms. In this discussion, it can be seen that Bundo Kanduang has full power in managing the needs of the family as well as having the responsibility to maintain and process the inheritance of the people in order to stay alive and meet the needs of all family members.

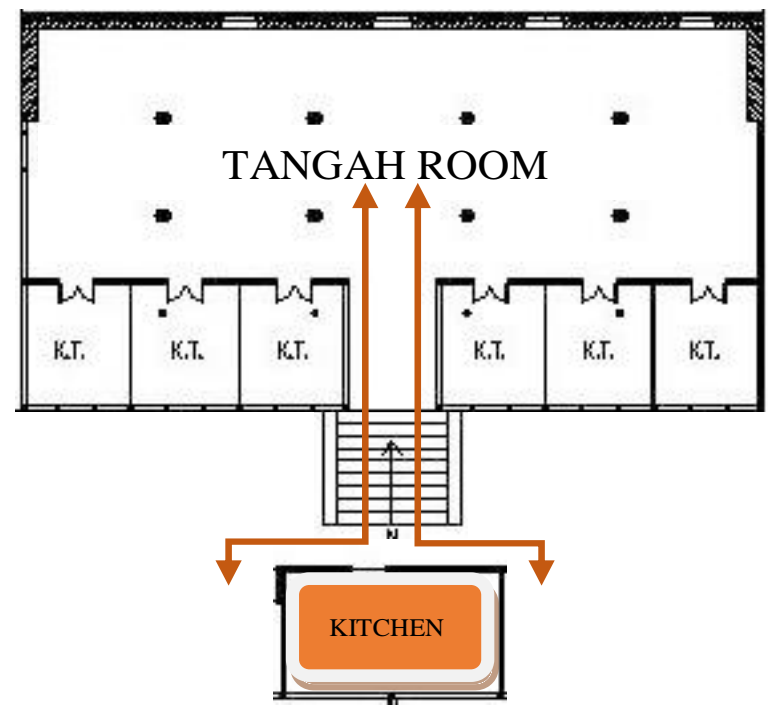

Fig. 6. Bundo Kanduang circulation at the entrance to the rumah gadang and the kitchen

\section{Mamaliharo anak dan kemenakan (nurturing children and nephews).}

The location of the bedrooms (bilik/KT) is a physical facility in a rumah gadang, placed in a row in front of the living room (Figure 7). The size of the bedroom is relatively small, which is only enough to 
put a bed, cupboard and chest to store valuables. This shows that the residents of the rumah gadang must be active outside the home in order to improve the quality of life for themselves and their people.

The bedroom area, located at the back of the gadang house, shows that Minangkabau customs protect women, provide privacy, and elevate their status. If you want to meet guests, you can do it in the middle area which is open in front of each bedroom, so that you can see each other among the residents of the rumah gadang, especially seen by Bundo Kanduang, so that they can keep each other safe from evil deeds or the actions of the occupants themselves, which are prohibited by religion.

The position of the rooms that are physically parallel shows the similarity of the position and degree of the occupants of the rumah gadang. In addition, it also makes it easier for Bundo Kanduang to supervise, guard, collect, and ensure that his children and nephews are safe, peaceful, and have their basic needs met. The bedroom in the rumah gadang is used and passed on to daughters as the successors of the lineage.

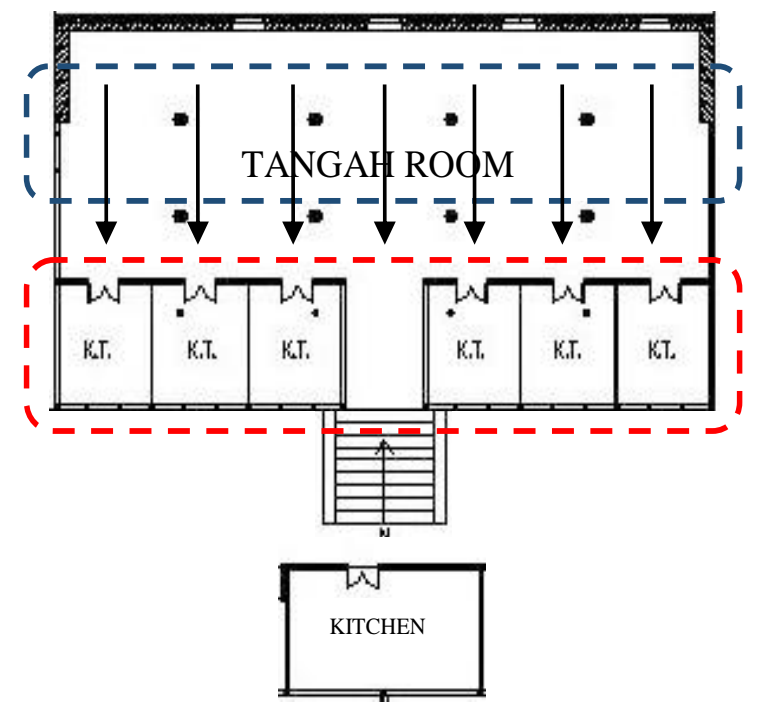

Fig. 7. The position of the cubicle (bedroom) is lined up in front of the living room, making it easier for Bundo Kanduang to supervise his children and nephews

\section{CONCLUSION}

Aspects of norms, views of life or culture of the typical Minangkabau society produce a conception and form of space that shows the interaction and reciprocal relationship between humans and space. Facilities that are physically built (first place) in the rumah gadang building, are the imagination space (second space) of the predecessors as a space that can support the duties and obligations of Bundo Kandung.
Bundo Kandung as the central figure in the matrilineal understanding of the tribes in Minangkabau has used the space in the rumah gadang, as a facility for the activities of Bundo Kandung.

The existing facilities are in accordance with the concepts of their predecessors and their meaning can still be felt today, which is a form of third space, which is a combination of physical space and imagination. The third space in the rumah gadang is very supportive of the activities of the duties and obligetions of Bundo Kandung so that they can carry out their roles well and can bring their people in a better direction.

\section{ACKNOWLEDGMENT}

Thanks are conveyed to the promoter of the Doctoral Study Program of Fine Arts and Design. Faculty of art and Design. Institut Teknologi Bandung: Prof. Dr. Yasraf Amir Piliang., MA; Deddy Wahjudi., ST., M.Eng., Ph. D; Dr. Ruly Darmawan., S.Sn., M.Sn. As well as the Interior Design Study Program, Faculty of Arts and Design, Trisakti University for the opportunities and facilities provided.

\section{REFERENCES}

Bustami. (1988). Kedudukan dan Peranan Wanita Dalam Kebudayaan Bangsa Minangkabau. Departemen Pendidikan dan Kebudayaan, 1-4.

Ernatip., D. S. (2014). Kedudukan dan Peran Bundo Kanduang Dalam Sistem Kekerabatan Matrilineal di Minangkabau, Balai Pelestarian Nilai Budaya Padang, Padang, 80-97.

Hardono, S., Bahauddin, A., Abdullah, A., \& Maliki, N.Z. (2014). The Matrilineal Architectural Values on the Construction of the Minangkabau House, DIMENSI-Journal of Architecture and Built Environment, 41(1), 51-58.

Le Comte, M. D., \& Goetz, J. P. (1982). Problems of Reliability and Validity in Ethnographic Research, Review of Educational Research, 51.

Marthala, A. E. (2013). Rumah gadang, Kajian Filosofi Arsitek Minangkabau.Humaniora. Bandung.

Penghulu, Idrus Hakimy DT. Rajo. (1994). Pegangan Penghulu, Bundo Kanduang, dan Pidato Alua Pasambahan Adat di Minangkabau. Remaja Rosdakarya Offset, Bandung, 94-105.

Penghulu, Idrus Hakimy DT. Rajo. (1978). Buku Pegangan Bundo Kanduang di Minangkabau. CV Rosda, Bandung, 21-31.

Rapoport, A. (1974). House Form and Culture, Prentice Hall, Inc., New Jersey.

Rapoport, A. (1980). Human Aspects of Urban Form, Pergamon Press, Oxford. 
Soja, E. (1996). Third Space, Journey to Lost Angeles and Other Real and Imagined Places, Blackwell Publishers, U.K, 8-11, 60-82.

Triatmodjo, S. (2010). Permufakatan dan Desakralisasi Ruang di Permukiman Kauman Yogyakarta, Disertasi, Jurusan Teknik Arsitektur, Fakultas Teknik, Universitas Gadjah Mada.
Triatmodjo, S. (2015). Membangun Lokalitas Ruang Kota (Building Up Locality in Urban Space). Ars (Jurnal Seni rupa \& Desain), 18(1), 1-8.

Wardani, L. K. (2010). Fungsi, Makna dan Simbol (Sebuah Kajian Teoritik). In: Seminar Nasional Jelajah Arsitektur Nusantara 101010, Institut Teknologi Surabaya. 